6. Holland N. Reading and Identity, 1998. URL: http://www.clas.ufl.edu/ users/nholland/ rdgident.htm.

7. Holland N. N. Unity Identity Text Self. Reader-Response Criticism : From Formalism to Post-Structuralism / Ed. by Jane P. Tompkins. Baltimore, 1980. P. 118-133.

8. Suleiman S. R. Wimmers I. C. The Reader in the Text: Essays on Audience and Interpretation. [S. 1.] : Princeton University Press, 1980. 441 p.

DOI https://doi.org/10.30525/978-9934-26-073-5-1-78

\title{
СУБ'СКТИВНІ ТРАНСФОРМАЦІЇ ХУДОЖНЬОГО НАРАТИВУ: КОГНІТИВНИЙ АСПЕКТ
}

\author{
Мацевко-Бекерська Л. В. \\ доктор філологічних наук, професор, \\ завідувач кафедри світової літератури \\ Львівського національного університету імені Івана Франка \\ м. Львів, Украӥна
}

Парадигматика новітньої наратології засвідчує оприявнення того методологічного феномену, коли кожен наступний поворот «лінзи поляроїда» вияскравлює щоразу нові можливості розпросторення наукового дискурсу, розгортає дедалі ширшу термінологічну й аналітичну перспективу. Вочевидь, класична, а далі - посткласична наратологія здійснила наступний після свого «перевороту» крок, повернувши в бік когнітивістики. Теорія художнього викладу продуктивно асимілює ідеї зближення із когнітивною психологією, чиє зацікавлення становить те, «як люди здобувають інформацію про світ, як ця інформація подається людиною, як вона зберігається у пам'яті та перетворюється у знання і як ці знання впливають на нашу увагу та поведінку» (переклад з російської мій. -Л.М.-Б.) [6]. І якщо для когнітивної психології $є$ важливим і цінним «весь діапазон психологічних процесів - від відчуттів до сприймання, розпізнавання образів, уваги, навчання, пам'яті, формування понять, мислення, уяви, запам'ятовування, мови, емоцій і процесів розвитку» [6], то цілком очевидним $\epsilon$ безпосередній зв'язок етапів художнього викладу із кожним названим елементом когнітивного ланцюжка. Це, зокрема, відзначає Р. Савчук, апелюючи до Ж. Женетта і О. Трубіної: «наратологія постає, принаймні, у двох функціональних перспективах. По-перше, вона лишається 
частиною теорії літератури, з ії пильною увагою до наративу (у вузькому розумінні, власне текстовому вимірі, - оповіді) як матеріальної форми, як мовлення оповідного тексту $<\ldots>$ У широкому розумінні, наратив постає фундаментальним компонентом соціальної взаємодії, який виконує функції створення та передачі соціального знання, а також самопрезентації індивідів» $[4$, с. 216]. Отож, серед численних концептів когнітивної наратології чільне місце належить суб'єктивності / суб'єктивованості презентації історії з її подальшими репрезентаціями у свідомості читача. Погоджуємося також із окресленими дослідницею двома ключовими проблемами, над якими варто розмислити в дискурсі когнітивної наратології: 1) «яким чином визначається й чим зумовлюється когнітивний статус оповіді» та 2) як «розпізнати спосіб, в який ми вибудовуємо і розуміємо наратив, у тому числі художній, зважаючи на наші когнітивні компетенції» [4, с. 218]. Так, площина об'єктивації художнього наративу набуває дещо модифікованого вигляду - читач стає активним учасником «оживання» наратованого світу, активізуючи певний когнітивний етап у здійсненні цілісного сприймання літературнохудожнього феномену. Читачеві належить значна відповідальність: спочатку слід пройти шляхом автора (щоби в рецептивній площині повернутися до зародження інтенційного задуму), згодом - відтворити послідовність наративних елементів у розгортанні первинної ідеї, зрештою, сформувати власну інтенційну настанову щодо історії та іiі репрезентації, дотримуючись водночас усіх посутніх координат викладу (щодо часової перспективи, тривалості, модальності, перцептивних аспектів тощо). Для окреслення рецептивної парадигми художнього наративу слід зважити на виокремлені в сучасному літературознавстві три форми оприявнення читацької присутності в матриці літературноестетичної комунікації: «1) реальне історичне обличчя, яке ми відновлюємо на підставі історичних документів певної епохи; 2) читач, якого ми уявляємо, виходячи 3 наших знань про соціальну та історичну ситуацію тієї чи іншої епохи; 3) читач, роль якого запрограмована в тексті» [1, с. 221]. 3 позицій когнітивної наратології кожна форма вияву рецептивної сутності увиразнює певний елемент психологічного ланцюжка народження смислу.

«Реальне історичне обличчя», з огляду на об'єктивну співпричетність до духу та настроїв доби, майже синхронно актуалізуватиме відчуття у процесі сприймання (діючи за аналогією), розпізнаватиме образи через миттєве відтворення того, що зауважено в дійсності, а формування естетичного досвіду триватиме значно довше, ніж процес безпосередньо (про)читання та перших інтерпретацій. Культурно-історичний контекст 
$\epsilon$ надійною запорукою тотожності когнітивно-творчого та когнітивнорецептивного процесів, при цьому найменше місця залишиться для (мало)(не)виправданих очікувань, а читач може гармонійно відбутися як співтворець сенсу попри його особисте ставлення до реального (історичного) автора. Для читача цього типу лише додаткову роль виконують маркери дійсності, позаяк він розуміє мову знаків та символів, семантика підтексту $є$ невід'ємним атрибутом його розуміння сучасності. На моделювання репептивної площини більше впливає самість читача, ніж інтенція творця. Завдяки спільним координатам епохи світоглядні вектори максимально зближують два когнітивні ланцюжки: творення і сприймання.

Другий тип читача є результатом вторинної суб’єктивації: уявивши або дослідивши історико-культурний контекст, намагаємося змоделювати інші (= відмінні від першого сприймання) рецептивні рефлексії художнього наративу. Щодалі від історичності творення, то більшою $є$ частка непевності та гіпотетичності. Часовий інтервал істотно трансформує когнітивний ланцюжок. Він розгортається від уяви й мислення у зворотному напрямку: через розпізнавання образів до сприймання та формування цілісного діапазону естетичних реакцій (від відчуттів до оцінки). Суб'єктивність стає атрибутом рецепції та інтерпретації, в художньому наративі читач шукає самого себе, а комунікація відбувається в межах рецептивної свідомості. На рівні когнітивних процесів кожен етап є сам собі питанням і відповіддю: читач адресує запитання не авторові 3 його інтенційними засновками, а самому собі 3 власними очікуваннями чи сподіваннями. У проекції читача виразно змінюється пропорція: він стає «радше активним, ніж пасивним», він демонструє значно більше ознак «комплексу індивідуальних реакцій», аніж позиціонує себе частиною «актуалізації колективної компетенції». Художній наратив забезпечує тривання життя твору, застерігає його текстову ідентичність, однак естетичні координати постають на значно ширшій інтерпретаційній площині. Для цього типу читача істотною є проблема збереження автора як сенсотвірної основи, позаяк віддалення від історичності примножує онотологічні смисли. 3 одного боку, дозволена читацька свобода, з другого - виникає нагальна потреба дотримуватися правил та обмежень, встановлених самим автором. Когнітивний процес ускладнюється, адже пам'ять і творення образів повинні актуалізовуватися синхронно, відчуття і знання не перебувають у причиннонаслідкових зв'язках, а балансують в межах художнього світу як реальне та уявне тощо. 
Третій тип читача - «читач, роль якого запрограмована в тексті» постулює константні атрибути рецепції і реалізовує когнітивний процес у спосіб, передусім та безпосередньо визначений наративними засобами. Загально кажучи, «щоб здійснитись, літературний текст потребує читацької уяви, яка надає форми взаємодії корелятів, накреслених у структурі порядком речень» [2, с. 352]. Так само «порядок речень» забезпечує рух рецептивних зусиль, формує настрій першого сприймання і визначає стратегію читання загалом. Формальні засоби організації наративу зосереджуються на чіткому визначенні «точок опори» в сенсотворенні, в образотворенні, в парадигматиці проблем чи поетикальних прийомів. Читацька рефлексія грунтується на сумі першого i теперішнього прочитань твору, але включає також вже як здобуте, так i примножене цим текстом значення: «читання вилучає синхронність колективної рецепції, воно іiі ієрархізує, структурує і перетворює у складний багатоступеневий процес» [1, с. 26]. Власне когнітивні засновки цих трансформацій становлять значний інтерес для дослідження форм і прийомів організації художнього тексту. Явлений наративом читач не лише вбирає суму набутих текстом значень, він передбачає ймовірні запитання до автора, він може визначити окремі перестороги щодо вихідного смислу, авторського задуму, розмаїтих позалітературних впливів на творчий процес.

У літературознавчому дискурсі однаково важливими є дві актуальні проблеми: «перша проблема - це світ художнього тексту та «уявний» чи гіпотетичний читач, який перебуває поза межами тексту <... Друга проблема - це читач у структурі художнього тексту, тобто читацька присутність як художній феномен, що полягає в ії здатності бути початком, який організовує художне ціле» [1, с. 47]. Таким чином, два основні модуси - «модус потенційності» та «модус дійсності» моделювання читацької присутності в художньому просторі, на думку А. Компаньона, узгоджуються з принциповими підходами до літератури: «при формально-об'єктивному підході до літератури головну увагу звертають на твір; при підході міметичному - на зовнішній світ; зрештою, при прагматичному підході - на публіку, читацьку аудиторію» [3, с. 164].

Отож, когнітивно-наратологічна диференціація читача як органічної складової художнього дискурсу максимально зближує прагматичний підхід до літератури із можливостями дослідження трансформацій тексту в проекції на сприймання як психологічний процес та як початок розбудови множини інтерпретацій. Беручи до уваги цілком слушне питання, яке сформулював О. Собчук: «що ж є предметом вивчення 
когнітивної наратології: текстуальні структури чи структури людського мислення?» [5, с. 12], можемо вважати, що акцент на певному типі читацького оприявнення дає підстави для пошуку способів, що забезпечують взаємотрансформацію структур обох класів.

\section{Література:}

1. Зубрицька M. Homo legens: читання як соціокультурний феномен. Львів. Літопис, 2004. 352 с.

2. Ізер В. Процес читання, феноменологічне наближення. Слово. Знак. Дискурс: [антологія світової літературно-критичної думки ХХ ст. / за ред. М. Зубрицької]. Львів: Літопис, 2001. С. 349-368.

3. Компаньон А. Демон теории. М. Изд-во Сабашниковых, 2001. 307 c.

4. Савчук Р. I. Когнітивна наратологія в контексті нових дослідницьких орієнтирів сучасної лінгвістики тексту. Проблеми семантики слова, речення та тексту. Bun. 31. 2013. С. 214-220.

5. Собчук О. В. Переосмислення понять наративності, персонажа i фокалізації в сучасній конітивній наратології. Магістеріум. Випуск 48. Літературознавчі студіï. 2012. С. 108-113.

6. Солсо Р. Л. Когнитивная психология. М. Тривола, 1996. URL: http://flogiston.ru/library/solso 